\title{
A Comparative Study on Dimensions of Role Efficacy between Top and Middle Management of Universities in Rajasthan
}

\author{
Chaudhary A.K.*, Jain N.**
}

\begin{abstract}
Role Efficacy showed higher Organizational effectiveness. This depicts that with higher role efficacy in the organization, the employees were more effectively. The purpose of the present research work is to compare role efficacy of top and middle management employees of universities of Rajasthan. Respondents were directly contacted for filling up the standard questionnaire of Role Efficacy Scale, developed by Dr. Udai Pareek. The ten dimensions of role efficacy namely (Centrality, Self-role integration, Proactivity, Creativity, Inter-role linkage, Helping relationship, Superordination, Influence, Personal growth and Coordination ) were analysed through t-test. The results conclude that there is significant differences on dimension (self role integration, creativity and inter role linkage) of role efficacy of top and middle management. The significance of the study is based on the challenges facing higher education and to improve their academic standard through role efficacy of top and middle level management.
\end{abstract}

Key words: Role efficacy, Top management, Middle management

\section{Introduction}

The word "university" is derived from the Latin word universitas magistrorum et scholarium, which roughly means "community of teachers and scholars." The university's employees played different roles in the university to execute various tasks. They have required proficiency in his jobs so we have to needed study of role efficacy of employees of universities. Role Efficacy showed higher Organizational effectiveness. This depicts that with higher role efficacy in the organization, the employees were more effectively Role efficacy mean's a person's capacity for producing a desired result or effect; effectiveness. In other words it means potential effectiveness of an individual occupying a particular role in university.

* Dr. Ajay K. Chaudhary, Senior Lecturer, Department of Psychology, Government Meera Girls College, Udaipur (Raj.)

** Ms. Namrata Jain, Research Scholar, Faculty of Management, Pacific University, Udaipur. 


\section{Review of Literature}

Tochukwu M. Oguegbe et. al. (March, 2014) research conducted on "Role of Self -Efficacy and Sex on Work Centrality among Workers" This study investigated the role of self-efficacy and sex on work centrality among workers. Work centrality is an important psychological construct that can influence a variety of work related outcome as well as impact a person's life beyond work. This study has an accumulated research work on centrality and furthered our under finding of its network. People who value work as an important part of their life, are committed to their organization and occupation, remain with their organization longer, make money, experience less psychological symptoms and are more satisfied with their job and life. They work longer hour and are ready to embark on any challenging task without fear of failure, and commit themselves less to activities outside of their work environment

Objectives of the Study: The objectives of the present research are as follows:

1. To study the role efficacy in the Top and Middle Management employees of universities of Rajasthan.

2. To study the various dimensions of role efficacy namely Centrality, Self-role integration, Proactivity, Creativity, Inter-role linkage, Helping relationship, Superordination, Influence, Personal growth and Coordination of university employees.

3. To compare the various dimensions of role efficacy between Top and Middle Management employees of universities.

4.

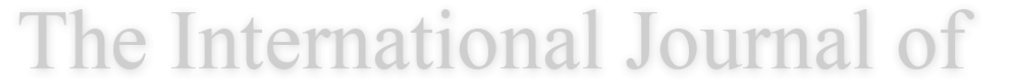

Methodology: First of all the head of the institutions were contacted and after taking permission for data collection, respondents were contacted at their comfort zone of time. Then the Role Efficacy Scale questionnaires were distributed and collected after 45 minutes. Thereafter scoring was done with the help of manual and interpretation was done. Thereafter t-test was applied for the comparison of top and middle management university employees in the context of various dimensions of role efficacy.

Tool: RES (Role Efficacy Scale) by Udai Pareek was used. The scale consists of 10 dimensions of role efficacy namely Centrality, Self-role integration, Proactivity, Creativity, Inter-role linkage, Helping relationship, Superordination, Influence, Personal growth and Coordination. The test is reliable (reliable coeffincient 0.68 ) and valid (validity coefficient 0.51 )

\section{Research Design}

Data were collected from 270 employees drawn from Public, Private and Deemed Universities. For testing the differences on present role efficacy between Top and Middle management, the distribution of sample is as follows: Top management $=180$; Middle management $=90$.

Sample: The sample consisted of a total number of 180 top management (academic) and 90 employees middle management from six universities of Rajasthan.

\section{ANALYSIS AND DATA INTERPRETATION}

There will be no significant difference among Top and Middle Management regarding dimensions of role efficacy namely Centrality, Self-role integration, Proactivity, Creativity, 
Inter-role linkage, Helping relationship, Superordination, Influence, Personal growth and Coordination of University's employee.

Comparison of Top and Middle Management on dimensions of Role efficacy

\begin{tabular}{|c|c|c|c|c|c|c|c|}
\hline Dimensions & $\begin{array}{c}\text { Type of } \\
\text { Management }\end{array}$ & $\mathbf{N}$ & Mean & S.D. & $\begin{array}{c}\text { Mean } \\
\text { Diff }\end{array}$ & $\mathbf{t}$ & p value \\
\hline \multirow[t]{2}{*}{ Centraility } & Top & 180 & 2.13 & .994 & \multirow[t]{2}{*}{.144} & \multirow[t]{2}{*}{1.141} & \multirow[t]{2}{*}{.255} \\
\hline & Middle & 90 & 1.99 & .954 & & & \\
\hline \multirow{2}{*}{$\begin{array}{l}\text { Self-role } \\
\text { integration }\end{array}$} & Top & 180 & 2.94 & 1.282 & \multirow[t]{2}{*}{.361} & \multirow[t]{2}{*}{2.192} & \multirow[t]{2}{*}{.029} \\
\hline & Middle & 90 & 2.58 & 1.263 & & & \\
\hline \multirow[t]{2}{*}{ Proactivity } & Top & 180 & 2.02 & 1.307 & \multirow[t]{2}{*}{.167} & \multirow[t]{2}{*}{.989} & \multirow[t]{2}{*}{.324} \\
\hline & Middle & 90 & 1.86 & 1.303 & & & \\
\hline \multirow[t]{2}{*}{ Creativity } & Top & 180 & 2.87 & 1.073 & \multirow[t]{2}{*}{.283} & \multirow[t]{2}{*}{2.028} & \multirow[t]{2}{*}{.044} \\
\hline & Middle & 90 & 2.59 & 1.101 & & & \\
\hline \multirow[t]{2}{*}{ Inter-role linkage } & Top & 180 & 2.79 & 1.251 & \multirow[t]{2}{*}{.367} & \multirow[t]{2}{*}{2.280} & \multirow[t]{2}{*}{.023} \\
\hline & Middle & 90 & 2.42 & 1.236 & & & \\
\hline \multirow{2}{*}{$\begin{array}{l}\text { Helping } \\
\text { relationship }\end{array}$} & Top & 180 & 2.51 & 1.676 & \multirow[t]{2}{*}{.206} & \multirow[t]{2}{*}{.953} & \multirow[t]{2}{*}{.341} \\
\hline & Middle & 90 & 2.30 & 1.659 & & & \\
\hline \multirow[t]{2}{*}{ Superordination } & Top & 180 & 1.57 & 1.473 & \multirow[t]{2}{*}{.156} & \multirow[t]{2}{*}{.831} & \multirow[t]{2}{*}{.407} \\
\hline & Middle & 90 & 1.41 & 1.405 & & & \\
\hline \multirow[t]{2}{*}{ Influence } & Top & 180 & 2.12 & 1.363 & \multirow[t]{2}{*}{.183} & \multirow[t]{2}{*}{1.048} & \multirow[t]{2}{*}{.296} \\
\hline & Middle & 90 & 1.93 & 1.339 & & & \\
\hline \multirow[t]{2}{*}{ Personal Growth } & Top & 180 & 2.27 & 1.217 & \multirow[t]{2}{*}{.133} & \multirow[t]{2}{*}{.866} & .388 \\
\hline & Middle & 90 & 2.13 & 1.144 & & & \\
\hline Coordination & Top & 180 & 3.42 & 1.182 & .244 & 1.580 & .115 \\
\hline & Middle & 90 & 3.18 & 1.232 & & & \\
\hline
\end{tabular}

The above table shows that ' $t$ ' score for centraility dimension of role efficacy is found to be 1.141 which is insignificant at 0.05 level it infers that there is no significant difference on centraility dimension of role efficacy between top and middle management. The above table indicates that ' $\mathrm{t}$ ' score for self-role integration dimension of role efficacy is found to be 2.192 which is significant at 0.05 level it infers that there is significant differences on self-role integration dimension of role efficacy between top and middle management. The above table reflects that ' $t$ ' score for proactivity dimension of role efficacy is found to be 0.989 which is insignificant at 0.05 level it infers that there is no significant difference on proactivity dimension of role efficacy between top and middle management. The above table depicts that ' $t$ ' score for creativity (C) 2014 www.ijip.in July-September $2014 \quad 140 \mid \mathrm{P}$ a g e 
The International Journal of Indian Psychology: Volume: 01 | Issue: 04 No. 2 | ISSN 2348-5396

dimension of role efficacy is found to be 2.028 which is significant at 0.05 level it infers that there is significant differences on creativity dimension of role efficacy between top and middle management. The above table reveals that ' $t$ ' score for inter-role linkage dimension of role efficacy is found to be 2.280 which is significant at 0.05 level it infers that there is significant differences on inter-role linkage dimension of role efficacy between top and middle management. The above table observes that ' $t$ ' score for helping relationship dimension of role efficacy is found to be 0.953 which is insignificant at 0.05 level it infers that there is no significant difference on helping relationship dimension of role efficacy between top and middle management. The above table refers that ' $t$ ' score for superordination dimension of role efficacy is found to be 0.831 which is insignificant at 0.05 level it infers that there is no significant differences in superordination dimension of role efficacy between top and middle management. The above table exhibits that ' $\mathrm{t}$ ' score for influence dimension of role efficacy is found to be 1.048 which is insignificant at 0.05 level it infers that there is no significant difference on influence dimension of role efficacy between top and middle management. The above table refers that ' $t$ ' score for personal growth dimension of role efficacy is found to be 0.866 which is insignificant at 0.05 level it infers that there is no significant difference on personal growth dimension of role efficacy between top and middle management. The above table exhibits that ' $t$ ' score for coordination dimension of role efficacy is found to be 1.580 which is insignificant at 0.05 level it infers that there is no significant difference on coordination dimension of role efficacy between top and middle management.

\section{Interpretation}

- Centrality dimension of Role Efficacy Top and Middle management do not differs significantly on Centrality dimension of organizational role efficacy. It may be due to both types of management have similar level of potential effectiveness.

- Self Role Integration dimension of Role Efficacy Top and Middle management differs significantly on Self Role Integration dimension of organizational role efficacy. Top management had significantly more Self Role Integration from Middle management it may be due to Top management have more strength, experiences, and special skills to make Self Role Integration. 
- Proactivity dimension of Role Efficacy Top and Middle management do not differs significantly on Proactivity dimension of organizational role efficacy. Top and middle management have to similar power to executes all decision with take initiative at university level.

- Creativity dimension of Role Efficacy Top and Middle management differs significantly on Creativity dimension of organizational role efficacy. Top management had significantly more Creativity from Middle management it may be due to Top management having more opportunities to be creative and they used new and unconventional ways to solving problems then Middle management.

- Inter Role Linkage dimension of Role Efficacy Top and Middle management differs significantly on Inter Role Linkage dimension of organizational role efficacy. Top management had significantly more Inter Role Linkage from Middle management it may be due to Top management executes important role in the university by nature organization.

- Helping Relationship dimension of Role Efficacy Top and Middle management do not differs significantly on Helping Relationship dimension of organizational role efficacy. Top and Middle management having equally Helping Relationship it may be due to Top and Middle management executes strategic Planning and implement to entire organization.

- Superordination dimension of Role Efficacy Top and Middle management do not differs significantly on Superordination dimension of organizational role efficacy at university level. It may be due to they have serve at similar level of systems, groups and entities beyond the organization.

- Influence dimension of Role Efficacy Top and Middle management do not differ significantly on Influence dimension of organizational role efficacy. It may be due to they have similar power to Influence larger section of society.

- Personal Growth dimension of Role Efficacy Top and Middle management do not differs significantly on Personal Growth dimension of organizational role efficacy. It may be due to Top and Middle management employees have more and similar opportunities for personal growth.

- Confrontation dimension of Role Efficacy Top and Middle management do not differ significantly on Confrontation dimension of organizational role efficacy. It may be due to 
Top and Middle management are super position holders to listen the employee's problem and solve them

\section{Findings}

The Top management perform more better on self-role integration, creativity and inter-role linkage in comparison of middle management at university level. It was found that there is significant difference in dimension of role efficacy between top and middle management.

\section{Conclusions}

There is significant difference between Top and Middle management on dimension Self-role integration, Creativity and Inter-role linkage.

\section{Recommendations}

1. Top management maintained all three main subsystems of role efficacy such as self-role integration, creativity and inter-role linkage. While middle management required all three subsystem.

2. The Role Efficacy refresher program for both levels top and middle should be organized, so that employees can perform better at both levels.

Limitation of the Study: This research is limited to the top and middle management of educational sector of Rajasthan. This study relied on self report and surveyed data.

\section{References}

Tochukwu M. Oguegbe et. al. (2014) "Role of Self-Efficacy and Sex on Work Centrality among Workers” International Journal of Humanities and Social Science Vol. 4, No. 5(1). 